\title{
Marine Environment Conservation
}

\author{
Shivakumar $\mathbf{M}^{*}$ and Gangadharagowda \\ Department of Aquatic Environment Management, Animal and Fisheries Sciences University, India
}

Submission: February 09, 2019; Published: February 22, 2019

Corresponding author: Shivakumar M, Department of Aquatic Environment Management, Animal and Fisheries Sciences University, Mangalore-575 002, India

\section{Opinion}

The marine environment includes the waters of seas and estuaries, the seabed and its sub soils, and all marine wildlife and its coastal habitats. The marine environment is a vital resource for life on earth. It is a precious asset; a heritage that must be protected, conserved and properly valued. Marine ecosystems perform several key environmental functions; they regulate the climate, prevent erosion, accumulate and distribute solar energy, absorb carbon dioxide, and maintain biological control. The seas and oceans are our greatest source of biodiversity. They cover $71 \%$ of the earth's surface and they contain $90 \%$ of the biosphere. The marine environment is also a great contributor to economic prosperity, social well-being and quality of life. About $70 \%$ of the oxygen we breathe comes from oceans and $90 \%$ of the carbon we produce ends up in oceans. It is the protection and preservation of ecosystems in oceans and seas through planned management in order to prevent the exploitation of these resources. The formation of dead zones in the oceans, loss of biodiversity, ocean acidification, depleting fish stocks, sinking of small islands, plastic pollution are the marine ecosystem. Environmental biologists must be able to connect the dots among marine biology, oceanography, fisheries science, international marine laws, sociology, policy and governance and other related issues to bring noticeable changes. It constitutes a fund of resources which can be used to achieve greater economic potential.

The major challenges and issues of concerns related to marine resources are:

a. Global governance of the marine environment, in the highly sensitive areas of conservation

b. Use of deep-water resources

c. Application of the ecosystem-based approach to the management of human activities impacting the marine environment.

d. Monitoring and assessment issues; challenge of hazardous substances.
Effective conservation and management of marine resources requires a comprehensive understanding of ecosystem structure and function. Through concerted and persistent data collection, researchers and resource managers can gain an understanding of these ecosystem components. The monumental herculean task of surveying, recording and cataloging an immense liquid wilderness can be daunting for managers. Establishing monitoring programs at a scale large enough to appropriately monitor marine communities is frequently cited as a stumbling block to effective management services in marine and coastal areas [1]. Under the Medium-Term Strategy of United Nation Environment Program (UNEP), the Marine and Coastal Strategy has been developed by the UNEP Marine and Coastal Ecosystems Branch (MCEB) to focus on priority issues for maintaining marine ecosystems and their services for human well-being.

The strategy's vision can be achieved through a long-term plan that outlines what is needed to improve our marine and coastal environments and ultimately reduce human impact through four objectives:

A. Land-Ocean Connections: To integrate the management of coastal watersheds, the coastal area (including cities) and the marine environment to optimize the ecosystem services and resilience of marine and coastal systems.

B. Ecosystems for Human Well-Being: To identify, assess and value the status, key drivers of change and services of marine and coastal ecosystems and their link to human wellbeing.

C. Reconciling Use and Conservation: To ensure that appropriate governance frameworks, management tools, capacity and options are available for regions, countries, communities and the private sector to effectively engage in the sustainable management of marine and coastal ecosystems including reconciling competing uses.

D. Vulnerable People and Places: To strengthen the ecological, economic and social security of vulnerable 
communities and places, including Small Island Developing States (SIDS) to adapt and respond to natural disasters and climate change, through enhancing the resilience of marine and coastal ecosystems and social capital, and improved access and benefit sharing

MCEB provides a comprehensive institutional and programmatic framework for regional and global cooperation for the protection of the marine environment. It hosts the Marine Ecosystems Unit (MEU), the Global Programme of Action for the Protection of the Marine Environment from Land based Activities (GPA), and the Regional Seas Programme (RSP). Regional stakeholders can closely work with these organizations and make participatory policies which are acceptable for most of the beneficiaries.

\section{Marine Ecosystems Unit (MEU)}

The MEU undertakes marine environmental and resource management related work through the development and provision of tools, guidelines and implementation of demonstration projects, for example through ecosystem-based adaptation, climate change vulnerability assessments and adaptive marine spatial planning projects.

Global Programme of Action for the Protection of the Marine Environment from Land based Activities (GPA)

The GPA aims to mitigate and prevent the degradation of the marine environment from land-based activities by facilitating the realization of the duty of States to preserve and protect the marine environment. It is the only global programme addressing the interface between freshwater and the coastal environment and encourages countries to develop National Programmes of Action (NPA) to address priority issues based on the needs and capacities of their economies and institutions. Other areas of focus include hazardous waste, nutrients, marine litter, pesticides and wastewater [2].

\section{Regional Seas Programme (RSP)}

The RSP aims to address the accelerating degradation of the world's oceans and coastal areas through the sustainable management and use of the marine and coastal environment, by engaging neighbouring countries in comprehensive and specific actions to protect their shared marine environment. Main areas of focus include biodiversity, land-based sources of pollution, capacity building and education/awareness.

In India too, we have many programs, namely Bay of Bengal Program (BOBP). This is an Inter-Governmental Organisation mandated to enhance cooperation among member countries, other countries and organisations in the region and provide technical and management advisory services for sustainable coastal fisheries development and management in the Bay of Bengal region [3].

\section{Approaches}

Strategies and techniques for marine resources and fisheries conservation tend to combine theoretical disciplines, such as population biology, with practical conservation strategies and laws such as those listed below:

\section{Management Programs}

i. Voluntary Marine Conservation Areas

ii. Education of the public about conservation issues

iii. Training and capacity building of stakeholders (Fisheries/mining/shipping/aqua sport/capture fisheries)

iv. Interdepartmental platforms

v. Promote development of increased passion, efficiency, transparency, sense of ownership, loyalty, valuable relationship with the environment

vi. Global linkages - exchange programs and collaborations for strong institutional capacity building

\section{Technological Issues}

i. Developing sustainable fisheries and restoring the populations of endangered species through artificial means.

ii. Viable biotechnological approaches for degradation of oils and fats, control of fouling organisms, control of bloom

iii. Zero waste technology for companies along the coasts

\section{Policies}
a. Setting up of National Marine Environment Conservation Academy
b. Integration of organizations and develop common vision, strategy, delivery process
c. Human and institutional networking for shared goals
d. Prioritization of roles and deliverables in tune with magnitude of the problem

e. Marine protected areas (MPAs) or Voluntary Marine Conservation Areas.

f. Fishing quotas

g. Marine protected areas (MPAs)

h. Nature FIRST programs

There are many special programs around the world working on marine environment conservation. One such project called Green Fins that uses the SCUBA diving industry to educate the public based in South East Asia. This project, implemented by UNEP, encourages scuba diving operators to educate the public they teach to dive about the importance of marine conservation and encourage them to dive in an environmentally friendly manner that does not damage coral reefs or associated marine 
ecosystems. Another focus of conservationists is on curtailing human activities that are detrimental to either marine ecosystems or species through policy, techniques such as, like those set up by the Northwest Atlantic Fisheries Organization, or recognizing the economics involved in human use of marine ecosystems is key, as is education of the public about conservation issues. This includes educating tourists that come to an area that might not be familiar of certain rules and regulations regarding the marine habitat.

\section{Conclusion}

Though there is a progressive improvement in science and technology in last two centuries, its growth is phenomenal and faster during last three decades. Its consequences on coastal waters and marine environment pollution are significantly increasing. Despite many international organizations are in place with right aim and objectives, unless there is people participation as movement in conserving natural resources, nothing can be achieved significantly. This calls for continuous awareness among different stakeholders, good institutional networks and people participation. Otherwise, we cannot escape the consequences for escaping the responsibilities. Let us work together and preserve our environment.

\section{References}

1. Baird BE, Miller-Henson M, Semmens BX (2000) Improving California's system of marine managed areas: Final report of the state interagency marine managed areas workgroup In: Ocean resources management program, Resource agency of California, USA

2. Carleton, Ray G (2014) Marine conservation: science, policy, and management. In: McCormick-Ray, Jerry Hoboken (Eds.) WileyBlackwell, USA

3. European Commission (2006) Environment fact sheet: Protecting and conserving the marine environment.

Your next submission with Juniper Publishers will reach you the below assets

- Quality Editorial service

- Swift Peer Review

- Reprints availability

- E-prints Service

- Manuscript Podcast for convenient understanding

- Global attainment for your research

- Manuscript accessibility in different formats

( Pdf, E-pub, Full Text, Audio)

- Unceasing customer service

Track the below URL for one-step submission https://juniperpublishers.com/online-submission.php 